\author{
효모배양물 첨가 사료가 계사내 유해가스 발생 및 육계의 \\ 생산성에 미치는 영향 \\ 박재홍*.류명선*김상호**.나종삼***김종승***.류경선* \\ 전북대학교 동물자원과학과 전북대학교 바이오식품 소재개발 및 산업화 연구센터*, \\ 축산기술연구소 대전지소**, 익산대학교 산업연구소***
}

\title{
Influence of Supplemental Dietary Yeast Culture on the Noxious Gas Emission in Broiler Houses and Performance of Broiler Chicks
}

\author{
J. H. Park*, M. S. Ryu*, S. H. Kim**, C. S. Na***, J. S. Kim*** K. S. Ryu* \\ Dept. of Animal Resources and Biotechnology, Research Center for Industrial Development of \\ Biofood Materials, Chonbuk National University*, National Livestock Research Institute**, \\ Institute of Industrial Technology, Iksan National College***
}

\begin{abstract}
Two experiments were conducted to investigate the effect of dietary supplementation of yeast culture on the performance of broiler chicks and noxious gas emission in broiler houses. Two hundred forty and three hundred and twenty, one day old Cobb male broiler chicks in Expt 1 and Expt 2, respectively were alloted to four treatment levels of yeast culture $(0,0.1,0.2,0.4 \%)$. To each treatment, 60 birds were assigned in Expt 1 and 5 replicates of 16 birds each were assigned in Expt 2. Basal diets contained $21.5 \%$ and $19.0 \% \mathrm{CP}$, and $3,100 \mathrm{kcal} / \mathrm{kg} \mathrm{ME}$ for the starting and finishing periods, respectively. Ammonia and $\mathrm{CO}_{2}$ gas emission were detected twice a day for seven days during the five week period of Expt 1. Weight gain, feed intake and feed efficiency were measured for five weeks in Expt 2. Intestinal microbes, blood cholesterol and ND antibody titer were examined at the end of Expt 2.

In Expt 1, the concentration of $\mathrm{NH}_{3}$ in the house of birds fed yeast culture tended to be lower than the control. It was significantly lower in the $0.4 \%$ yeast culture treatment than the control $(\mathrm{P}<0.05) . \mathrm{CO}_{2}$ concentration was significantly lower in all yeast culture treatments regardless of its dietary supplemental level than the control $(\mathrm{P}<0.05)$.
\end{abstract}

In Expt 2, weight gain of birds fed $0.2 \%$ yeast culture tended to be higher, but not significantly

이 논문은 과학기술부·한국과학재단 지정, 전라북도 지원 지역협력연구센터인 전북대학교 바이오식품 소 재 개발 및 산업화 연구센터의 연구비 지원에 의해 연구되었음.

Corresponding author: Kyeong Seon Ryu, Department of Animal Resources and Biotechnology, College of Agriculture, Chonbuk National University, Chonju 561-756 Korea E-mail: seon@moak. chonbuk.ac.kr 
different from others. Feed efficiency (feed/gain), however, was significantly improved in all yeast culture treatments relative to that of the control for starting period $(\mathrm{P}<0.05)$ and that of $0.2 \%$ yeast culture treatment was significantly lower than those of the control and $0.4 \%$ for the overall period. Total number of E. coli in the ileum of birds fed yeast culture at 0.1 and $0.2 \%$ was significantly lower than those of the control and $0.4 \%$ in the ileum. The CFU of Lactobacillus spp. of birds fed yeast culture at $0.1 \%$ was higher in the cecum compared to other treatments $(\mathrm{P}<0.05)$. Total cholesterol level of chicks fed $0.1 \%$ yeast culture seemed to be lower compared to that of other treatments, whereas LDL-cholesterol level was significantly lower than those of the control and $0.4 \%$ treatment. ND antibody titer tended to be higher in the yeast culture treatments than the control, but was not significantly different.

The results of these experiments indicated that $0.2 \%$ yeast culture may have a potential to reduce the noxious gas emission in broiler houses and maximize the performance of broiler chicks.

(Key words : Broiler chicks, Noxoius gas, Yeast culture, Performance, Cholesterol)

\section{I. 서 론}

가축용 사료에 지속적인 항생제의 첨가는 축 산물 조직내 잔류와 내성으로 사용에 많은 제 약이 따르며, 최근 유럽 연합에서는 인수 공통 으로 적용되는 항생제에 대하여 사료용 첨가제 로는 대부분 규제하고 있다. 따라서 가축의 사 육에 이러한 항생제의 문제점을 배제할 수 있 고 자연적으로 안전한 효모제 및 생균제와 같 은 환경친화형 사료첨가제의 활용에 대한 연구 가 진행되어 왔다(Krause 등, 1989; Krueger 등, 1990; Stanley 등, 1993; 박 등, 2002).

효모는 가금에 우수한 단백질, 에너지 및 인 의 공급원으로서 함유황 아미노산과 비타민 $\mathrm{B}_{12}$ 를 제외한 다른 영양소는 대두박과 비슷하 게 함유되어 있다(Yoshida, 1975). 육계사료에 이러한 효모(Saccharomyces cerevisiae)의 첨가. 급여는 비타민, 효소(Krause 등, 1989), 단백질 (Crumplen 등, 1989) 및 미지성장인자를 공급하 여 스트레스를 완화하고(Phillips와 Von tungeln, 1984), 사료 효율(Krueger 등, 1990)을 개선한다 고 보고 되어왔다. 또한 효모는 가용 미네랄이 함유되어 골격의 이상을 예방하고 지방의 소화 율을 개선하며 phytase를 생성하여 피틴태인의 이용율을 향상시킨다고 하였다(Thayer 등, 1978). 이외에도 McGinis(1992)는 육계전기 사 료에 bacitracin 대체로 효모배양물과 유산균 혼 합제를 급여시 효모 급여구에서 사료효율과 생
존율이 개선되었고 곰팡이 균의 피해가 감소되 어 bacitracin을 효과적으로 대체할 수 있다고 보고하였다. 그리고 박 등(2002)은 육계에 효모 제제를 급여한 결과 생산성, 장내 미생물, 혈청 의 $\mathrm{IgG}$ 에 있어서 유의한 차이는 없었으나 항생 제(CTC)와 같거나 증가하는 경향을 보였다고 하였다. Stanley 등(1993)은 aflatoxin이 감염된 육계 사료에 Saccharomyces cerevisiae를 첨가하 여 급여시 효모 급여구는 대조구에 비해서 증 체량이 증가하였고 간과 심장의 무게가 현저하 게 감소하였으며, 혈액의 albumin, total protein 농도, enzyme, transaminase 및 creatine phosphokinase의 활력이 증가하였다고 보고하였다. 효 모는 장내 혐기성 세균의 증식을 도와 가축의 생산성을 개선하는 사료첨가제로서 장내 유산 균의 생장을 촉진하여 유해 세균(coliform, enterococci)의 수를 감소시켜 장내 환경을 양호 하게 하고 영양소의 소화흡수에 최적 상태를 유지한다고 하였다(Shin 등, 1990). 또한 Rose (1989)는 효모가 소장내에서 산소를 이용하기 때문에 산소를 필요로 하는 장내 유해 미생물 의 증식이 억제되고 장내 혐기성 유산균의 증 식을 촉진시킴으로서 가축의 생산성을 향상시 킨다고 하였다.

그러므로 본 연구는 육계사료에 효모배양물 을 수준별 급여가 계사내 유해가스 발생 및 육 계의 생산성, 장내 미생물 및 혈액의 콜레스테 롤에 미치는 영향을 구명하고자 시행하였다. 


\section{ㅍ. 재료 및 방법}

\section{1. 사양실험}

본 실험은 (주)하림으로부터 1일령 Cobb 수 컷을 구입하여 5 주간 2 회의 사양실험을 시행하 였다. 사료내 영양소 함량은 사육전기 3 주와 후기 2주로 분리하여 각각 CP $21.5 \%$ 및 $19 \%$ 와 $\mathrm{ME}$ 는 $3,100 \mathrm{kcal} / \mathrm{kg}$ 으로 하였고, 기타 영양소 함량은 Table 1에 나타내었다. 본 실험에 이용 된 효모배양물은 (주)여산에서 구입하였으며 균수는 $10^{6} \mathrm{cfu} / \mathrm{g}$ 이고, 사료내 효모배양물 수준은 $0,0.1,0.2,0.4 \%$ 로 급여하였다. 실험 1 에서는 처리구당 60 수씩 총 240 수를 환경조절형 계사 에 배치하였으며, 실험 2 에서는 처리구당 5 반 복, 반복당 16 수씩 전체 320 수를 이용하였다.

\section{2. 조사항목}

\section{(1) 계사내 유해가스 측정}

계사내 암모니아와 이산화탄소는 오전 10:30 시와 오후 5:00시에 각각 10 분간 밀폐한 후 7 일 동안 Gastec(GV-100, Japan)을 이용하여 측 정하였다.

\section{(2) 증체량, 사료섭취량, 사료요구율}

체중은 매주 일정한 시각에 측정하였고 사료 섭취량은 체중 측정시 반복별로 사료잔량을 측 정하여 구하였다. 또한 사료요구율은 사료섭취 량을 증체량으로 나누어 산출하였다.

\section{(3) 장내 미생물수 조사}

실험 종료 후 처리구별로 5 수씩 조사하였으 며 회장 내용물은 Meckel's diverticulum 하단부 에서 채취하고 맹장 내용물은 2 개의 맹장 내용 물을 모두 취하였다. 장 내용물은 멸균된 생리 식염수 $9 \mathrm{ml}$ 에 중량 대 부피로 $10^{-1}$ 부터 $10^{-5}$ 까 지 단계 희석하여 선택배지에 접종하였다. Salmonella, E. coli, Lactobacillus, yeast의 colony를 측정하기 위하여 SS agar, MacConkey agar, Rogosa agar, yeast morphology agar를 이 용하였고 $39^{\circ} \mathrm{C}$ 에서 24 시간(Lactobacillus는 48 시
간)동안 호기 및 혐기상태로 배양(Table 2)한 후, 각각의 평판배지에서 colony의 수를 조사하 였다. 조사된 미생물의 수는 $\log _{10}$ 을 취하여 표 기하였다.

\section{(4) Cholesterol}

혈액은 처리구별로 10 수씩 채취한 다음 고정 된 상태에서 3 시간 동안 $4^{\circ} \mathrm{C}$ 에서 응고시킨 후 $3,000 \mathrm{rpm}$ 에서 10 분간 원심분리하였다. 분리된

\section{Table 1. Basal diet composition}

\begin{tabular}{lrc}
\hline Ingredients & $\begin{array}{c}\text { Starter } \\
(0 \sim 3 \mathrm{wks})\end{array}$ & $\begin{array}{c}\text { Finisher } \\
(4 \sim 5 \mathrm{wks})\end{array}$ \\
\hline \hline & $\ldots \ldots \ldots \ldots \ldots \ldots$ & $\ldots \ldots \ldots \ldots$ \\
Corn & 61.18 & 66.48 \\
Soybean meal(44\%) & 24.24 & 24.78 \\
Soybean oil & 2.00 & 2.00 \\
Corn gluten meal & 8.66 & 3.71 \\
TCP & 1.75 & 1.18 \\
Limestone & 1.19 & 1.14 \\
L-methionine & 0.11 & 0.05 \\
L-lysine HCL & 0.20 & 0.12 \\
Salt & 0.47 & 0.34 \\
Vitamin premix ${ }^{1)}$ & 0.10 & 0.10 \\
Mineral premix ${ }^{2)}$ & 0.10 & 0.10 \\
Total & 100.00 & 100.00 \\
\hline
\end{tabular}

Calculated Nutrient composition

$\begin{array}{lrr}\text { ME(kcal/kg) } & 3,100 & 3,100 \\ \mathrm{CP}(\%) & 21.50 & 19.00 \\ \mathrm{Ca}(\%) & 1.00 & 0.90 \\ \mathrm{P}(\%) & 0.45 & 0.34 \\ \text { Methionine(\%) } & 0.50 & 0.38 \\ \text { Lysine(\%) } & 1.10 & 1.00\end{array}$

1) Provided per kilogram of diet : vit A, 5,500 IU; vit $\mathrm{D}_{3}, 1,100 \mathrm{ICU}$; vit $\mathrm{E}, 11 \mathrm{IU}$; vit $\mathrm{B}_{12}, 0.0066 \mathrm{mg}$; riboflavin, $4.4 \mathrm{mg}$; pantothenic acid, $11 \mathrm{mg}$ (Ca-pantothenate: $11.96 \mathrm{mg}$ ); choline, $190.96 \mathrm{mg}$ (choline chloride $220 \mathrm{mg}$ ); menadione, $1.1 \mathrm{mg}$ (menadione sodium bisulfite complex $3.33 \mathrm{mg}$ ); folic acid, $0.55 \mathrm{mg}$; pyridoxine, $2.2 \mathrm{mg}$ (pyridoxine hydorchloride, $2.67 \mathrm{mg}$ ); biotin, $0.11 \mathrm{mg}$; thiamin, $2.2 \mathrm{mg}$ (thiamin mononitrate $2.40 \mathrm{mg}$ ); ethoxyquin, $125 \mathrm{mg}$.

2) Provided the mg per kilogram of diet : Mn, 120; $\mathrm{Zn}, 100 ; \mathrm{Fe}, 60 ; \mathrm{Cu}, 10 ; \mathrm{I}, 0.46$ and $\mathrm{Ca}, \min : 150$, $\max : 180$. 
Table 2. Media and culture conditions for microbial organisms

\begin{tabular}{lll}
\hline Microbial organisms & \multicolumn{1}{c}{ Selective media } & \multicolumn{1}{c}{ Culture conditions } \\
\hline \hline Salmonella & SS agar(Difco 0074-17) & Surface plate, $39^{\circ} \mathrm{C}$ for $24 \mathrm{hr}$ \\
E. coli & MacConkey agar(Difco 0075-17-1) & Surface plate, $39^{\circ} \mathrm{C}$ for 24hr \\
Yeast & Yeast morphology agar(Difco 0393-17) & Surface plate, $39^{\circ} \mathrm{C}$ for $24 \mathrm{hr}$ \\
Lactobacillus & Rogosa agar(Difco 0480-17-0) & Surface plate, $39^{\circ} \mathrm{C}$ for $48 \mathrm{hr}$ \\
\hline
\end{tabular}

혈액의 상층액인 혈청을 분리하여 $-70{ }^{\circ} \mathrm{C}$ 의 냉 동실에 보관한 후 분석시 이용하였다. 혈청 총 콜레스테롤, 중성지방, HDL-cholesterol을 효소 비색법을 이용한 분석 $\operatorname{kit}(\mathrm{AM} 202-\mathrm{K}$, 아산제 약)로 측정하였다. 그리고 LDL-cholesterol은 Friedewald(1972)의 방법으로 계산하였다.

\section{(5) Newcastle disease(ND) 항체가}

$\mathrm{ND}$ 항체가는 14 일령에 1 차 접종하고 28 일령 에 보강접종 후 분리된 혈청으로부터 10수씩 조사하였다. 항체가는 Beard 등(1975)의 혈액 응집 억제반응(Heamagglutination Inhibition test; $\mathrm{HI}$ test)을 이용하여 구하였으며, ND 항체 역가 는 $\log _{2}$ 값으로 나타내었다.

\section{3. 통계분석}

수집된 자료는 SAS package(1996)의 GLM procedure로 분산분석을 실시하였고, Duncan's new multiple range test(Steel과 Torrie, 1980)로
처리구간에 유의성 분석을 하였으며 신뢰수준 은 $95 \%$ 수준 $(\mathrm{P}<0.05)$ 으로 하였다.

\section{III. 결과 및 고찰}

1. 효모배양물의 수준별 급여가 계사내 유해 가스 발생에 미치는 영향

효모배양물의 수준별 급여가 환경 조절형 계 사내 암모니아와 이산화탄소가스 발생에 미치 는 영향은 Table 3 에 나타내었다. 오전에 측정 한 암모니아 가스 발생량은 효모배양물 $0.1 \%$ 와 $0.4 \%$ 급여구에서 대조구보다 유의하게 감소하 였고, 오후에 측정된 결과에서는 $0.4 \%$ 급여구가 대조구보다 유의하게 감소하였다. 이산화탄소는 오전과 오후에 측정한 결과, 대조구와 차이는 없었지만 감소하는 경향을 보였고 오전과 오후 의 평균치에 있어서는 효모배양물 급여구에서 대조구에 비하여 유의적으로 감소되었다. Allen (1991)는 닭에서 효모의 아미노산 소화율이 $98 \%$

Table 3. Influence of dietary supplemental yeast culture on noxious gas of broiler house in Expt 1

\begin{tabular}{|c|c|c|c|c|c|c|}
\hline \multirow{2}{*}{$\begin{array}{c}\text { Treatments } \\
(\%)\end{array}$} & \multicolumn{3}{|c|}{$\mathrm{NH}_{3}(\mathrm{ppm})$} & \multicolumn{3}{|c|}{$\mathrm{CO}_{2}(\mathrm{ppm})$} \\
\hline & AM 10:30 & PM 05:00 & Mean & AM 10:30 & PM 05:00 & Mean \\
\hline 0 & $29.00^{\mathrm{a}}$ & $26.43^{\mathrm{a}}$ & $27.50^{\mathrm{a}}$ & 2,580 & 2,486 & $2,525^{\mathrm{a}}$ \\
\hline 0.1 & $21.00^{\mathrm{bc}}$ & $25.71^{\mathrm{a}}$ & $23.75^{\mathrm{a}}$ & 2,300 & 2,243 & $2,267^{\mathrm{b}}$ \\
\hline 0.2 & $25.00^{\mathrm{ab}}$ & $22.86^{\mathrm{a}}$ & $23.75^{\mathrm{a}}$ & 2,340 & 2,329 & $2,333^{\mathrm{b}}$ \\
\hline 0.4 & $17.00^{\mathrm{c}}$ & $14.29^{\mathrm{b}}$ & $15.42^{\mathrm{b}}$ & 2,180 & 2,086 & $2,125^{\mathrm{b}}$ \\
\hline Pooled SE & 1.33 & 1.35 & 0.95 & 59.60 & 66.61 & 45.90 \\
\hline
\end{tabular}

a,b Means within a column with no common superscripts differ significantly $(\mathrm{P}<0.05)$. 
라고 하였고, Hibino 등(1974)은 효모의 단백질 소화율이 높다고 보고하였다. 따라서 효모배양 물의 급여는 장내 유익한 미생물의 우점을 도와 서 연변 방지 및 질소 이용율의 증가로 계사내 유해가스를 감소시키는 것으로 사료된다.

\section{2. 효모배양물의 수준별 급여가 육계의 생산} 성에 미치는 영향

육계사료에 효모배양물을 $0,0.1,0.2,0.4 \%$ 수준으로 급여시 증체량, 사료섭취량, 사료요구 율에 미치는 영향은 Table 4에 나타내었다. 사 육전기 3 주간에 증체량은 효모배양물 $0.2 \%$ 급 여구가 대조구와 다른 수준의 효모배양물 처리 구보다 높은 경향을 나타냈으나 통계적인 차이 는 없었다. 성장후기인 4 5주간의 증체량도 사 육전기와 비슷하게 $0.2 \%$ 처리구가 증가하는 경 향을 나타냈으며, 사육 전 기간의 증체량 역시 $0.2 \%$ 급여구가 다른 처리구보다 높았지만 유의 적인 차이는 없었다.

사료섭취량에 있어서 대조구는 효모배양물 급여구에 비하여 사육전기, 후기 및 전기간 동 안 증가하는 경향을 나타냈으나 통계적인 차이 는 없었다. 사육 전기의 사료요구율은 효모배 양물 급여구가 대조구보다 유의하게 개선되었 고, 사육후기에는 효모배양물 $0.2 \%$ 급여구가 대조구에 비하여 유의하게 개선되었다. 사육 전 기간의 사료요구율도 효모배양물 $0.2 \%$ 급여 구에서 대조구보다 유의하게 개선되었다. 본
실험의 결과, 효모배양물의 급여가 증체량과 사료섭취량에는 차이가 없는 것으로 나타났으 나 사료요구율은 $0.2 \%$ 급여구가 유의적으로 개 선되어 Krueger(1990)의 보고와 유사하였다. Glade와 Fist(1988)에 보고에 의하면 효모배양 물(S. cervisiae)의 첨가가 육계의 생산성을 개선 하는 이유는 직, 간접적으로 소화관을 따라서 흡수되는 질소 화합물의 전체 생물가가 증가하 기 때문이라고 하였고, 또한 Miller와 Balloun (1966)은 효모배양물(S. cervisiae)는 미지성장인 자를 함유하고 있기 때문이라고도 하였다.

3. 효모배양물 수준별 급여가 회장과 맹장의 미생물수 $\left(\log _{10} \mathrm{cfu} / \mathrm{g}\right)$ 에 미치는 영향

Table 5에서 보는 바와 같이 효모배양물의 급여로 회장과 맹장에서 살모넬라의 수는 대조 구와 차이가 없었으며, 회장의 E. coli는 효모 배양물 0.1 과 $0.2 \%$ 급여구가 대조구에 비하여 유의적으로 감소하였고 맹장에서는 차이가 없 었다. 회장내 Lactobacillus 는 효모배양물 $0.1 \%$ 급여구에서 다른 처리구보다 높아지는 경향을 보였으며, 맹장에서는 유의하게 증가하였다. Yeast의 수는 효모배양물 급여구에서 대조구에 비하여 감소되는 경향을 보였으나 통계적인 차 이는 없었다. 본 실험의 결과, 효모배양물의 급 여는 회장에서 E. coli를 감소시켰으며, 맹장의 Lactobacillus 는 유의하게 증가시키는 것으로 나 타났다.

Table 4. Influence dietary supplemental yeast culture on performance of broiler chicks in Expt 2

\begin{tabular}{|c|c|c|c|c|c|c|c|c|c|}
\hline \multirow{2}{*}{$\begin{array}{l}\text { Treatments } \\
(\%)\end{array}$} & \multicolumn{3}{|c|}{ Weight gain $(\mathrm{g})$} & \multicolumn{3}{|c|}{ Feed intake(g) } & \multicolumn{3}{|c|}{ Feed/gain } \\
\hline & $0 \sim 3 w k$ & $4 \sim 5 w k$ & Total & $0 \sim 3 w k$ & $4 \sim 5 w k$ & Total & $0 \sim 3 w k$ & $4 \sim 5 \mathrm{wk}$ & Total \\
\hline 0 & 566.3 & 848.0 & 1414.4 & 835.9 & 1956.0 & 2791.8 & $1.476^{\mathrm{a}}$ & $2.307^{\mathrm{a}}$ & $1.974^{\mathrm{a}}$ \\
\hline 0.1 & 564.1 & 844.3 & 1408.4 & 809.2 & 1886.3 & 2695.4 & $1.435^{\mathrm{b}}$ & $2.233^{\mathrm{ab}}$ & $1.914^{\mathrm{ab}}$ \\
\hline 0.2 & 585.3 & 866.5 & 1451.8 & 827.1 & 1806.0 & 2633.0 & $1.413^{\mathrm{b}}$ & $2.085^{\mathrm{b}}$ & $1.814^{\mathrm{b}}$ \\
\hline 0.4 & 569.4 & 810.2 & 1379.6 & 807.0 & 1922.3 & 2729.2 & $1.417^{\mathrm{b}}$ & $2.370^{\mathrm{a}}$ & $1.977^{\mathrm{a}}$ \\
\hline Pooled SE & 7.19 & 11.35 & 16.24 & 9.75 & 35.94 & 38.99 & 0.008 & 0.040 & 0.025 \\
\hline
\end{tabular}

a,b Means within a column with no common superscripts differ significantly $(\mathrm{P}<0.05)$. 
Table 5. Influence dietary supplemental yeast culture on the number of microflora in the intestinal content of broiler chicks in Expt 2

\begin{tabular}{|c|c|c|c|c|c|c|c|c|}
\hline \multirow{2}{*}{$\begin{array}{c}\text { Treatments } \\
(\%)\end{array}$} & \multicolumn{4}{|c|}{ Ileum } & \multicolumn{4}{|c|}{ Cecum } \\
\hline & Salmonella & E. coli & Lactobacillus & Yeast & Salmonella & E. coli & Lactobacillus & Yeast \\
\hline & \multicolumn{8}{|c|}{ 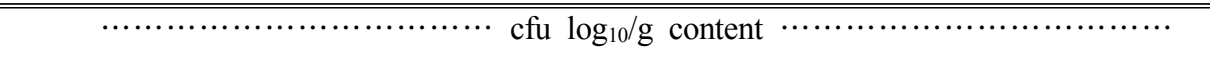 } \\
\hline 0 & 4.850 & $5.899^{\mathrm{a}}$ & 6.985 & 7.218 & 6.997 & 7.224 & $7.621^{\mathrm{b}}$ & 7.351 \\
\hline 0.1 & 4.850 & $4.560^{\mathrm{b}}$ & 8.068 & 5.699 & 6.209 & 6.796 & $8.428^{\mathrm{a}}$ & 7.038 \\
\hline 0.2 & 5.013 & $4.985^{\mathrm{b}}$ & 7.315 & 6.176 & 7.014 & 7.330 & $7.515^{\mathrm{b}}$ & 7.668 \\
\hline 0.4 & 5.710 & $6.128^{\mathrm{a}}$ & 6.886 & 6.176 & 6.537 & 6.462 & $7.176^{\mathrm{b}}$ & 6.889 \\
\hline Pooled SE & 0.126 & 0.370 & 0.191 & 0.341 & 0.188 & 0.180 & 0.139 & 0.166 \\
\hline
\end{tabular}

a,b Means within a column with no common superscripts differ significantly $(\mathrm{P}<0.05)$.

Brugier와 Patte(1975)에 의하면 효모배양물은 선위와 근위의 낮은 $\mathrm{pH}$ 에 적응하여 소장과 맹 장까지 도달하여 여러 종류의 병원성 세균에 대 한 antagonistic activity를 나타냈다고 하였으며, Line 등(1998)은 육계에 효모(S. boulardii)를 1, $100 \mathrm{~g} / \mathrm{kg}$ 을 각각 급여하여 맹장의 Salmonella와 Campylobacter colony를 조사한 결과, 효모 급여 구에서 Campylobacter의 수는 차이가 없었으나 Salmonella의 수는 현저하게 감소되었다고 하였 다. 한편, 이 등(1995)은 효모를 육계에 급여하 였을 때 소장과 맹장의 E. coli 균수가 대조구에 비하여 감소하였고, 유산균은 증가하였다고 하 여 본 실험의 결과와 비슷한 경향을 보였다.

4. 효모배양물의 수준별 급여가 혈장내 콜레 스테롤(HDL, LDL), 중성지방 및 $\mathrm{ND}$ 항 체가에 미치는 영향
총 콜레스테롤은 효모배양물 $0.1 \%$ 급여구에 서 $102.7(\mathrm{ml} / \mathrm{dl})$ 로 가장 낮았지만 대조구와 유의 적인 차이는 없었으며, $0.4 \%$ 급여구보다 유의 적으로 감소하였다 $(\mathrm{P}<0.05$; Table 6). $\mathrm{HDL}-$ cholesterol은 효모배양물 처리구에서 대조구보 다 높은 경향을 보였으나 통계적인 차이는 없 었다. LDL-cholesterol은 $0.1 \%$ 처리구가 53.15 $(\mathrm{ml} / \mathrm{dl})$ 로 대조구의 $74.28(\mathrm{ml} / \mathrm{dl})$ 보다 유의하게 감소하였다. 그리고 중성지방은 효모배양물 처 리구에서 대조구보다 감소하는 경향을 보였으 나 통계적인 차이는 없었다. 본 실험의 결과, S. cereviaise $0.1 \%$ 급여시 혈중 콜레스테롤과 중성지방이 현저하게 감소하였다는 Stanley 등 (1993)의 보고와는 다른 경향을 보였다. ND 항 체가는 효모배양물 급여구에서 증대되는 경향 을 보였는데 Corthier 등(1992)은 S. boulardii를 육계에 급여시 효모는 직접적으로 장내의 점막

Table 6. Influence of dietary supplemental yeast culture on blood cholesterol, triglyceride and ND antibody titer of broiler chicks in Expt 2

\begin{tabular}{cccccc}
\hline $\begin{array}{c}\text { Treatments } \\
(\%)\end{array}$ & $\begin{array}{c}\text { T-cholesterol } \\
(\mathrm{ml} / \mathrm{dl})\end{array}$ & $\begin{array}{c}\text { HDL } \\
(\mathrm{ml} / \mathrm{dl})\end{array}$ & $\begin{array}{c}\text { LDL } \\
(\mathrm{ml} / \mathrm{dl})\end{array}$ & $\begin{array}{c}\text { Triglyceride } \\
(\mathrm{ml} / \mathrm{dl})\end{array}$ & $\begin{array}{c}\text { ND AB } \\
\text { Titer }\end{array}$ \\
\hline \hline 0 & $117.14^{\mathrm{ab}}$ & 24.46 & $74.28^{\mathrm{a}}$ & 87.15 & 6.93 \\
0.1 & $102.70^{\mathrm{b}}$ & 33.55 & $53.15^{\mathrm{b}}$ & 65.81 & 7.53 \\
0.2 & $117.16^{\mathrm{ab}}$ & 29.87 & $69.83^{\mathrm{ab}}$ & 80.10 & 8.40 \\
0.4 & $134.66^{\mathrm{a}}$ & 39.05 & $76.90^{\mathrm{a}}$ & 76.71 & 7.13 \\
\hline Pooled SE & 3.46 & 2.80 & 3.57 & 5.62 & 0.26 \\
\hline
\end{tabular}

a,b Means within a column with no common superscripts differ significantly $(\mathrm{P}<0.05)$. 
에 작용한다고 하였고, Buts 등(1990)은 $\operatorname{IgA}$ 와 $\mathrm{Ig}$ 의 장내 분비를 증가시키기 위해 면역계를 자극하였다고 보고하여 이러한 작용에 기인한 것으로 사료된다.

\section{IV. 요 약}

본 연구는 효모배양물을 육계에 수준별로 급 여하여 두 차례의 사양실험을 시행하였다. 각 각의 실험에서 처리구는 사료내 효모배양물 수 준을 $0,0.1,0.2,0.4 \%$ 로서 전체 4 개의 처리구 를 두었다. 실험 1 에서는 처리구당 60 수씩 총 240 수를 환경조절형 계사에 수용하였으며, 계 사내 유해가스에 미치는 영향을 고찰하였다. 실험 2에서는 처리구당 5 반복, 반복당 16 수로 80 수씩 전체 320수를 이용하였으며, 육계의 생 산성, 장내 미생물의 변화, 혈중 콜레스테롤 및 $\mathrm{ND}$ 항체가를 측정하였다. 사육 전기 3 주간에 급여된 사료의 조단백질과 에너지 수준은 각각 $21.5 \%, \mathrm{ME} 3,100 \mathrm{kcal} / \mathrm{kg}$ 으로 하였으며 후기 2 주에는 $19 \%, \mathrm{ME} 3,100 \mathrm{kcal} / \mathrm{kg}$ 수준으로 급여하 였다. 실험 1 에서 효모배양물을 수준별로 급여 시 $0.4 \%$ 급여구에서 암모니아 가스 발생량은 다른 처리구에 비하여 감소하였고, 이산화탄소 는 모든 효모배양물 급여구에서 대조구보다 유 의하게 낮았다. 실험 2 에서 증체량은 효모배양 물 $0.2 \%$ 급여구가 대조구에 비하여 증가하는 경향을 보였으나 통계적인 차이는 없었고, 사 료섭취량 또한 처리구간에 차이가 없었다. 사 료요구율은 효모배양물 $0.2 \%$ 급여구가 대조구 보다 유의적으로 개선되었다 $(\mathrm{P}<0.05)$. 효모배양 물의 급여가 육계의 장내 미생물에 미치는 영 향은 $0.1,0.2 \%$ 급여구에서 회장의 E. coli가 대 조구와 비교하여 유의하게 감소하였고 $(\mathrm{P}<0.05)$, 맹장의 Latobacillus는 $0.1 \%$ 급여구에서 유의하 게 증가하였다. 혈중 총 콜레스테롤은 $0.1 \%$ 급 여구에서 유의적인 차이는 없었으나 감소하는 경향을 보였고, LDL-cholesterol 함량은 효모배 양물 $0.1 \%$ 급여구가 대조구에 비하여 유의하게 감소하였다. $\mathrm{ND}$ 항체가는 효모배양물의 급여 구에서 대조구보다 높아지는 경향을 보였지만 처리구간에 통계적인 차이는 없었다.
본 연구의 결과, 육계 사료에 효모배양물의 급여로 계사내 유해가스를 감소하였으며, 사료 요구율이 개선되었다. 그리고 장내 미생물과 콜레스테롤 수준에서도 변화를 나타내었다.

$$
\text { V. 사 사 }
$$

본 연구는 전북대학교 바이오식품 소재개발 및 산업화 연구센터의 지원으로 수행된 결과이 며 이에 감사드립니다.

\section{VI. 인 용 문 헌}

1. Allen, R. M. D. 1991. Ingestion and absorption of carbohydrates and protein. In: L. R. John(Ed) Phusiolgy of the Gastrointestinal Tract. Second Edition. Raven Press. NY. pp.1469.

2. Beard, C. W., Hopkins, S. R. and Hammond, J. 1975. Preparation of newcastle disease virus hemagglutination-inhibition test antigen. Avian Dis. 19:692.

3. Brugier, S. and Patte, F. 1975. Antagonisme in vitro entre l'ultra-levure et different germes bacteriens. Med. Paris 45:61.

4. Buts, J. P., Bernasconi, P., Vaerman, J. P. and Dive, C. 1990. Stimulation of secretory component of Sacchromyces boulardii. Dig. Dis. Sci. 35:251.

5. Corthier, G., Lucas, F., Jouvert, S. and Castex, F. 1992. Effect of oral Saccharomyces boulardii treatment on the activity of Clostridium difficile toxins in mouse digestive tract. Toxicon 30:1583.

6. Crumplen, R., D'Amore T., Panchal, C. J., Russell, I. and Stewart, G. G. 1989. Industrial uses of yeast: Present and Future. Yeast (Special issue) $5: 3$.

7. Friedewald, W. T., Levy, R. L. and Fredrickson, D. S. 1972. Estimation of the concentration of low-density lipoprotein chlesterol in plasma, without use of the preparative ultracentrifuge. Clin. Chem. 18:1163.

8. Glade, M. J. and Fist, M. D. 1988. Dietary yeast culture supplementation enhances urea recycling in the equine large intestine. Nutr. Rep. Int. 37:11.

9. Hibino, S., Tenashima, H., Minani, Z. and Kajita, 
M. 1974. Enzymatic digestion of yeast in some animals. Single Cell Protein. Proc. of. Int. Sym. Academic Press. N. Y. pp. 93.

10. Krause, O. G., Richardson, C. R., Castleberry, R. E. and Cobb, C. W. 1989. Biological response of chicks fed sorghum grain based diets with added grain specific enzymes mixture and yeast. (1989) Texas Tech of Agricultural Science, Lubbock. T5.263:7.

11. Krueger, W. F., Kassongue, A. and Ganguy, R. C. 1990. Effect of yeast added to the diet of broiler on performance to 28 to 49 days of age. Poultry Sci. 69:75(Abstr.).

12. Line, J. E., Bailey, J. S., Cox, N. A. and Stern, N. J. 1998. Effect of yeast treatment to reduce Salmonella and Campylobacter populations associated with broiler chicks subjected to transport stress. Poultry Sci. 76:1227.

13. McGinnis, K. 1992. Lacto-Sacc versus bacitracin in broiler starter diets. Biotechnology in the feed industry Proceeding 8th annual symposium. Alltech Publ. Kenturky. pp.49.

14. Miller, D. L. and Balloun, S. L. 1966. Unidentified growth factor sources in poult starter diets. Poultry Sci. 45:155.

15. Phillips, W. A. and Von Tungeln, K. L. 1984. Effect of adding yeast culture to the receiving ration of stressed stocker calves. Page 117 in: Anim. Sci. Rep. MP 116. Oklahoma State Univ., Agric. Exp. Station, Stillwater, OK.

16. Rose, A. H. 1980. Recent research on industrially important strains of Sacchromyces cerevisiae. In: Skinner, F. A, S. M. Passmore and R. R. Davenport(Ed.). Bilology and Activities of Yeast.
The society for Applied Bacteriology symposium Series No. 9. Academic Press, London. pp.103.

17. SAS/STAT. 1996. SAS user's guide. release 6.12 edition, SAS Inst. Inc., Cary, NC.

18. Shin, H. T., Bae, H. D., Chung, K. W., Kim, Y. K., Shon, J. H. and Lee, S. K. 1990. Evaluation of live yeast culture as source of probiotics for broiler. 5th AAAP:3:1.

19. Stanley, V. G., Ojo, R., Woldesenbet, S. and Hutchinson, D. H. 1993. The use of Sacchromyces cerevisiae to suppress the effects of aflatoxicosis in broiler chicks. Poultry Sci. 72: 1867.

20. Steel, R. G. D. and Torrie, J. H. 1980. Principles and Procedure of Statistics, McGraw Hill, New York.

21. Thayer, R. H., Burkitt, F. F., Morrison, R. D. and Murry, E. E. 1978. Efficiency of utilization of dietary phoshorus by caged turkey breeder hens when fed rations supplemented with live yeast culture. Okla. Agric. Exp. Stn. Res. Rep. MP103:173.

22. Yoshida, M. 1975. Yeast grown on n-paraffin as future poultry feed. World's Poultry Sci. 31:221.

23. 박대영, 남궁환, 백인기. 2002. Yeast Culture (Saccharomyces cerevisiae, Pichia pastoris)가 육 계의 생산성, 소장내 미생물 균총 및 혈청 $\mathrm{IgG}$ 농도에 미치는 영향. 동물자원과학회지 44:289.

24. 이현우, 김인호, 김춘수. 1995. 육계에 있어서 활 성효모(Saccharomyces cerevisiae)의 급여가 영양 소 이용성과 장내 미생물의 변화에 미치는 영향. 가금학회지 22:203.

(접수일자:2002. 10. 10 / 채택일자:2002. 12. 10) 